\title{
Pengaruh Kelompok Acuan Terhadap Minat Beli Konsumen (Studi pada Konsumen Yamaha NMAX di Kota Bandung)
}

\author{
Agri Regiansa \& Dadan Abdul Aziz Mubarok \\ STIE Inaba Bandung \\ Email: agriregiansa@gmail.com, dadan.aziz.mubarok@gmail.com
}

\begin{abstract}
This study aims to determine how respondents respond to the Reference Group and Buying Interest, and to see how much influence the Reference Group has on Buying Interest. The method used in this research is quantitative method. Data collection was carried out through a literature study and distributing questionnaires to 102 respondents. Sampling with purposive sampling. Data analysis uses simple Smart PLS analysis. The results showed that: Respondents' responses to the Reference Group, and Purchase Interest were in the good category by showing the results that the Reference Group had a strong positive effect on Buy Interest. The results of R Square, show that the magnitude of the influence of the Reference Group on Buying Interest is $32.1 \%$, the remaining $67.9 \%$ is influenced by variables not examined in this research model.
\end{abstract}

Keywords: Buy Interest, Reference group, Transportation and Yamaha NMAX

\section{Pendahuluan}

Pada saat ini transportasi merupakan sarana yang sangat dibutuhkan ditengah aktivitas sehari-hari masyarakat yang semakin banyak aktivitas dan sibuk, maka alat transportasi tersebut sangat dibutuhkan dalam menunjang kegiatan yang akan dilakukan para masyarakat. Sehingga dengan kesibukan tersebut, masyarakat menginginkan sebuah transportasi yang dapat melakukan kegiatan berpergian dengan cepat juga praktis dan salah satunya penggunaan sepeda motor. Transportasi di Indonesia didominasi oleh kendaraan roda dua, karena jika dilihat dari ukuran dan pengoperasiannya, sepeda motor merupakan alat transportasi yang sangat praktis digunakan, terlebih untuk menghindari masalah kemacetan, karena tingginya kemacetan yang ada dijalan raya membuat sepeda motor merupakan pilihan yang tepat untuk mempermudah dan mempercepat dalam melewati kemacetan saat menempuh perjalanan dan dapat menghemat waktu (Purwati et al, 2012).

Selain kesibukan beraktivitas, tingkat pertumbuhan penduduk juga merupakan faktor yang menyebabkan peningkatan permintaan sepeda motor. Pertumbuhan penduduk akan berpengaruh terhadap pertumbuhan ekonomi sehingga pertumbuhan ekonomi akan meningkatkan mobilitas seseorang dan kebutuhannya juga akan meningkat melebihi kapasitas prasarana transportasi yang tersedia. Sehingga semakin banyak pertumbuhan penduduk maka potensi permintaan akan sepeda motor juga meningkat hal ini dikarenakan kepadatan penduduk menyebabkan tingkat permintaan akan sepeda motor meningkat. Berdasarkan data badan pusat statistik Indonesia Tahun 2017, kendaraan sepeda motor mengalami peningkatan setiap tahun dalam waktu periode $2010-2017$. 
Penjelasan tersebut menggambarkan fenomena pengguna motor di Indonesia sehingga terdapat data perkembangan pengguna sepeda motor di Indonesia Tabel 1 Perkembangan Pengguna Sepeda Motor Periode 2010-2018 berikut:

Tabel 1. Perkembangan Pengguna Sepeda Motor Periode 2010-2018

\begin{tabular}{|c|c|c|}
\hline Tahun & $\begin{array}{c}\text { Pengguna Kendaraan } \\
\text { Sepeda Motor }\end{array}$ & Kenaikan pertahun (\%) \\
\hline 2010 & 61.078 .188 & - \\
\hline 2011 & 68.839 .341 & $12,70 \%$ \\
\hline 2012 & 76.381 .183 & $10,95 \%$ \\
\hline 2013 & 84.732 .652 & $10,93 \%$ \\
\hline 2014 & 92.976 .240 & $9,72 \%$ \\
\hline 2015 & 98.881 .267 & $6,35 \%$ \\
\hline 2016 & 105.150 .082 & $6,33 \%$ \\
\hline 2017 & 113.030 .793 & $7,49 \%$ \\
\hline 2018 & 123.361 .807 & $9,14 \%$ \\
\hline Rata-rata/tahun & $91.603 .505,888$ & $8.17 \%$ \\
\hline
\end{tabular}

Sumber : Badan Pusat Statistik Indonesia Tahun 2018 (diakses 2019)

Berdasarkan Tabel 1 di atas perkembangan pengguna sepeda motor di Indonesia, dilihat dari tabel tersebut dari tahun 2010, 2011, 2012, 2013, 2014, 2015, 2016, 2017 dan 2018 mengalami kenaikan dengan rata - rata kenaikan sebesar $8.17 \%$. Kondisi ini, diprediksi terus meningkat karena dalam waktu kurun 9 tahun yaitu selama periode tahun 2010 2018 pengguna sepeda motor di Indonesia mengalami kenaikan yang cukup pesat. Banyaknya jenis sepeda motor beredar baik produksi dalam negeri maupun produksi luar negeri, membanjirnya produk sepeda motor di pasaran ini sangat mempengaruhi sikap seseorang terhadap pembelian dan pemakaian barang. Minat beli Masyarakat Indonesia terhadap motor matic disesuaikan dengan selera desain motor yang ditampilkan dan besarnya jumlah kapasitas mesin yang dihasilkan (CC) semakin besar kapasitas mesin maka tenaga yang dihasilkan juga semakin besar seperti $125 \mathrm{CC}$ dan $150 \mathrm{CC}$. Salah satu Motor Matic yang memiliki kapasitas mesin $150 \mathrm{CC}$ adalah motor matic keluaran pabrik Yamaha yaitu Yamaha NMAX.

Yamaha NMAX memiliki keutamaan atau keunggulan - keunggulan dibandingkan motor matic 150cc yang lain, diantaranya adalah Mesin Blue Core 155 VVA yang Efisien, Bertenaga \& Handal, Dengan inverted LCD digital speedometer baru yang lebih stylish, modern, dan informatif bagi pengendara yang dilengkapi dengan 'Multi Information Display' (MID), eat Design mempadukan dua tekstur kombinasi dengan emboss logo NMAX yang disatukan dengan motif jahitan elegan membuat tampilan motor menjadi lebih berkelas, Mesin 155cc yang dilengkapi dengan Blue Core dan VVA (Variable Valve Actuation) membuat performa tarikan mesin lebih bertenaga, dan harga yang cukup terjangkau jika dibandingkan dengan spesifikasi yang dimiliki. Minat beli terhadap motor matic 150cc Yamaha NMAX dan Motor matic pesaingnya yaitu Honda PCX mengalami penurunan selama tiga bulan terakhir pada semester I Tahun 2018 seperti pada Gambar 1 Data Penjualan Yamaha NMAX dan Honda PCX Semester I tahun 2018 berikut ini : 


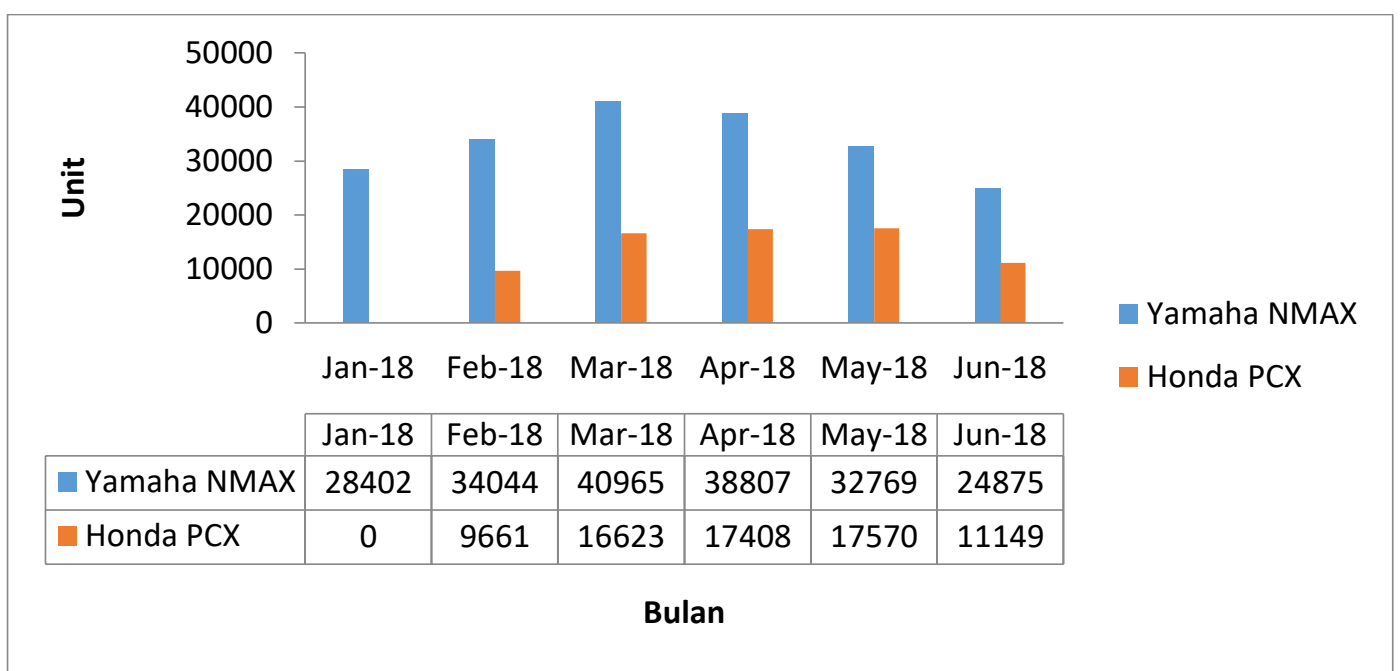

Gambar 1. Data Penjualan Yamaha NMAX dan Honda PCX Semester I tahun 2018 Sumber : https://www.aisi.or.id/statistic (diakses 2019)

Berdasarkan Gambar 1 di atas diketahui produk Yamaha NMAX mengalami fluktuasi pada bulan januari sampai maret mengalami rata-rata kenaikan sebesar $16,73 \%$ dan mengalami penurunan rata-rata sebesar $15,92 \%$ pada bulan april-juni. Penurunan ini disebabkan karena banyaknya pesaing yang bermunculan yang menjadikan penjualan Yamaha NMAX menurun. Informasi mengenai produk yang menyebabkan minat beli terhadap suatu produk didapat dari berbagai sumber. Penjualan Yamaha NMAX diatas menujukan bahwa minat beli konsumen terhadap produk telah muncul.

Kelompok Acuan hal ini diperkuat oleh hasil penelitian Nadiastika. et al (2016) yang menyebutkan bahwa terdapat pengaruh langsung dan signifikan antara kelompok acuan terhadap minat beli. Kelompok acuan merupakan salah satu tempat informasi yang didapat oleh konsumen, dimana review dan rekomendasi dianggap penting oleh beberapa orang. Kelompok acuan/kelompok referensi (reference group) adalah kelompok yang mempunyai pengaruh langsung (tatap muka) atau tidak langsung terhadap sikap atau perilaku orang tersebut (Kotler dan Keller, 2009:170). Agung (2014) dalam penelitiannya, menyebutkan bahwa kelompok acuan berpengaruh terhadap minat beli. Penelitian lain dilakukan David dan James (2017) terhadap minat beli, menjelaskan bahwa tidak ada pengaruh kelompok acuan terhadap minat beli. Dari fenomena kelompok acuan diatas terdapat data followers komunitas sepeda motor Yamaha Nmax di Instagram pada Tabel 1.2 Komunitas Nmax Bandung berikut:

Tabel 1. Komunitas Nmax Bandung

\begin{tabular}{|l|c|}
\hline \multicolumn{1}{|c|}{ Nama Komunitas Nmax Bandung } & Followers Instagram \\
\hline Bandung Nmax Community & 4424 \\
\hline Bandung Max Community & 15200 \\
\hline Baraya Max Bandung & 3208 \\
\hline Bandung Max Independent & 3812 \\
\hline Max Owner Bandung & 526 \\
\hline
\end{tabular}

Sumber : http://www.Instagram.com (diakses 2019) 
Berdasarkan data Tabel 2 diatas menjelaskan bahwa Bandung Nmax Community adalah salah satu komunitas yang diminati oleh pengguna sepeda motor Nmax dengan jumlah pengikut instagram sebanyak 4424. Salah satu alasan mengapa BNC diminati oleh pengguna sepeda motor Nmax adalah selain tidak dibatas usia, komunitas ini juga tidak memprioritaskan gender tertentu yang menjadikan komunitas motor yang satu ini jadi pilihan beberapa orang untuk dijadikan sebagai acuan dalam berkendara. Di era globalisasi ini tidak hanya komunitas yang dijadikan sebagai kelompok acuan namun ada hal lain yang dijadikan sebagai acuan dalam berkendara yaitu review dari pengguna motor NMAX yang selengkapnya disajikan dalam gambar 1.3 mengenai Komentar Riview Pengguna Motor NMAX:

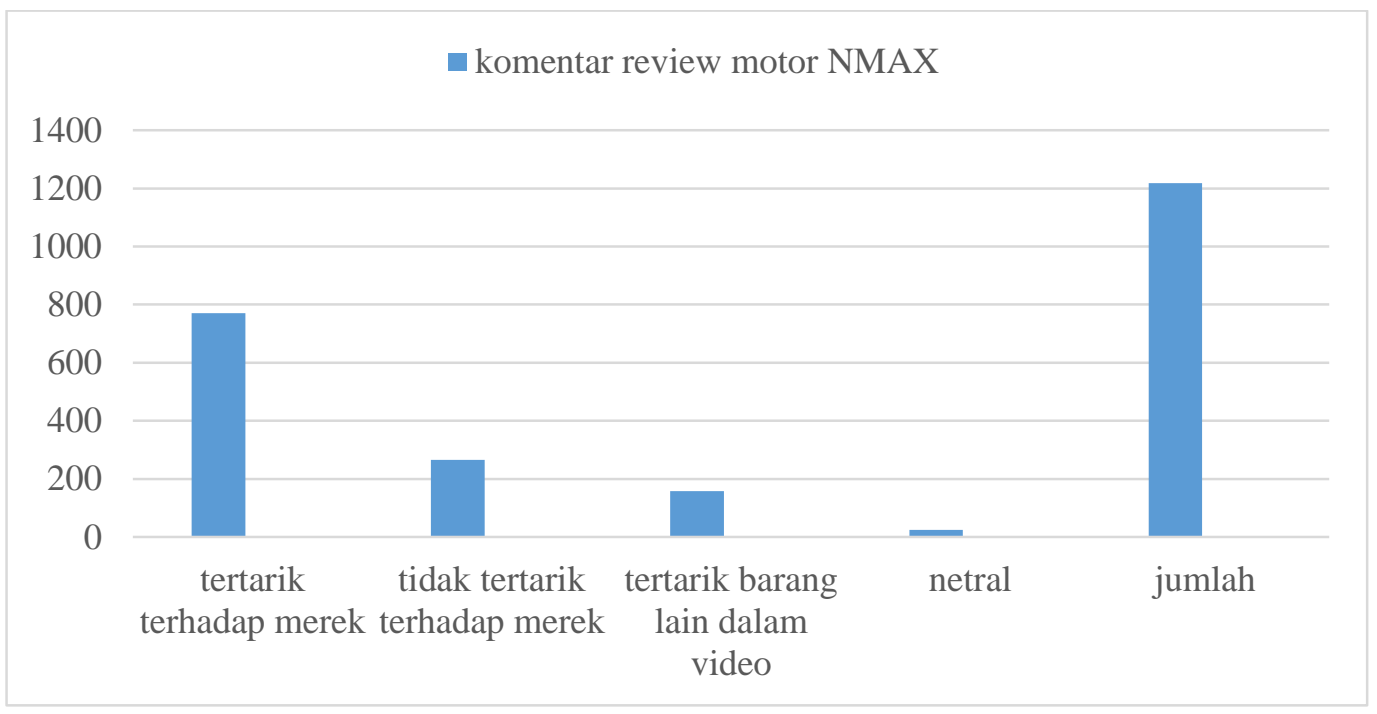

Gambar 2. Komentar Review Pengguna Motor NMAX

Sumber : Youtube Chanel Otomotif Tv (2 Desember 2019)

Berdasarkan Gambar 2 mengenai komentar review Pengguna Motor NMAX ternyata 770 dari 1.218 komentar mengenai review motor ini tertarik untuk memiliki motor merek NMAX dan memiliki keinginan untuk memiliki motor NMAX sementara 266 komentar tidak tertarik untuk memiliki motor merek NMAX,158 komentar tertarik barang lain dalam video seperti helm dan lain sebagainya yang ada dalam video dan 24 komentar diantaranya memilih berkomentar secara netral tidak mendukung maupun tidak menjatuhkan produk Yamaha NMAX dalam video review tersebut, hal menunjukan bahwa minat keingintahuan konsumen terhadap produk mulai muncul melalui review kelompok acuan diatas.

\section{Tinjauan Literatur}

Marketing Stimuli adalah setiap komunikasi atau stimuli secara fisik yang dirancang untuk mempengaruhi konsumen. Tools yang digunakan biasanya oleh perusahaan adalah variasi dari bauran pemasaran. Bauran pemasaran didefinisikan oleh beberapa ahli di bidang pemasaran antara lain Zeithaml (2009) menyatakan bahwa "marketing mix define as the element an organizations controls that can beused to satisfy or communicate with customer". Bauran pemasaran terdiri dari elemen-elemen dimana kesemuanya saling berinteraksi satu sama lain dan harus disesuaikan dengan tugas, rencana serta beberapa sumber daya yang dimiliki perusahaan. 
Menurut Setiadi (2013) minat beli adalah "Proses pengintegrasian yang mengkombinasikan pengetahuan untuk untuk mengevaluasi dua atau lebih perilaku alternatif dan memilih salah satu diantaranya. Hasil dari proses pengintegrasian adalah suatu pilihan yang disajikan secara kognitif sebagai keinginan berperilaku".

Schiffman dan Kanuk (2012) menyatakan bahwa minat merupakan salah satu aspek psikologis yang memiliki pengaruh cukup besar terhadap sikap perilaku. Penilaian konsumen terhadap produk tergantung pada pengetahuannya akan informasi tentang fungsi sebenarnya dari produk tersebut, dengan demikian konsumen yang berminat untuk melakukan pembelian suatu produk dipengaruhi oleh informasi yang diterima.

Berdasarkan definisi dari dua ahli diatas dapat diketahui bahwa minat beli merupakan kecenderungan konsumen dalam memilih alternatif produk dengan mencari informasi sebelum melakukan tindakan pembelian.

Menurut Durianto (2010) pembelian nyata merupakan sasaran akhir konsumen yang merupakan pernyataan mental konsumen yang merefleksikan perencanaan untuk membeli sejumlah produk dan merek tertentu. Lebih lanjutnya menurut Durianto (2010) mengungkapkan bahwa minat beli timbul karena adanya keyakinan konsumen terhadap suatu produk, dimana semakin rendah keyakinan konsumen terhadap suatu produk maka semakin rendah minat beli konsumen terhadap produk tersebut.

Minat beli terhadap suatu produk juga dapat terjadi dengan adanya pengaruh dari orang lain yang dipercaya oleh calon konsumen, konsumen juga terkadang merasa sangat tertarik terhadap berbagi informasi seputar produk yang diperoleh melalui iklan, pengalaman orang yang telah menggunakannya, dan kebutuhan yang mendesak terhadap suatu produk. Menurut Kotler (2012), dalam tahap evaluasi proses keputusan pembelian, konsumen membentuk kesukaaan/minat atas merek-merek dalam sekumpulan pilihanpilihan, konsumen juga mungkin membentuk minat untuk produk yang paling disukai.

Adapun Dimensi minat beli menurut Schiffman dan Kanuk (2012), indikator minat beli seorang konsumen adalah sebagai berikut: (1) Ketertarikan mencari informasi yang lebih tentang produk; (2) Mempertimbangkan untuk membeli; (3) Keinginan untuk mengetahui produk; (4) ketertarikan untuk mencoba produk.

Kelompok acuan adalah seluruh kelompok yang mempunyai pengaruh langsung maupun tidak langsung terhadap sikap atau perilaku seseorang. Beberapa diantaranya merupakan kelompok primer, yang dengan adanya interaksi yang cukup berkesinambungan, seperti keluarga, teman, tetangga, dan teman sejawat. Seseorang pada umumnya sangat dipengaruhi oleh kelompok acuan melalui tiga cara: (1) kelompok acuan memperlihatkan pada seseorang perilaku dan gaya hidup baru; (2) mereka juga mempengaruhi sikap dan konsep jati diri karena umunya 'ingin menyesuaikan diri'; (3) mereka menciptakan tekanan untuk menyesuaikan diri yang dapat mempengaruhi pilihan produk dan merek seseorang (Setiadi, 2013).

Kelompok acuan yang sering kali digunakan adalah sebagai berikut (Suryani, 2013): (1) Selebritis seperti penyanyi, pemain musik, artis, pelawak, atlit, eksekutif, dan politikus, merupakan orang-orang yang mempunyai popularitas tinggi dan pengaruh kuat terhadap konsumen di Indonesia. melihat kondisi ini, sering kali pemasar menggunakan selebritis sebagai bintang iklan dengan berbagai peran dalam komunikasi pemasaran; (2) Artis, penggunaan artis untuk mempromosikan produk dipandang mempunyai pengaruh yang 
cukup kuat karena popularitas mereka di masyarakat. Pemasar biasanya memilih artis yang sedang populer dan dikagumi khalayak sasaran yang menjadi pasar sasarannya. Terdapat empat macam peran artis dalam mempromosikan produk atau jasa, diantaranya memberikan kesaksian (testimonial), memberikan penguatan atau dorongan (endorsement), berperan sebagai aktor dalam iklan, dan berperan sebagai juru bicara perusahaan; (4) Pakar (Expert), pemasar sering menggunakan tokoh yang mempunyai kepakaran tertentu yang mempunyai relevansi dengan produk yang diiklankan, hak ini dilakukan agar konsumen semakin percaya bahwa produk yang diiklankan benar-benar mempunyai khasiat atau dianggap baik untuk digunakan.

Kelompok acuan adalah kelompok yang melibatkan satu atau lebih orang yang dijadikan sebagai dasar pembanding atau titik referensi dalam membentuk tanggapan afeksi dan kognisi serta menyatakan perilaku seseorang (Peter \& Olson, 2000 dalam Agus Budiyanto 2013). Kelompok acuan adalah kelompok pembanding dalam membentuk respon kognitif, afektif dan perilaku seorang konsumen yang melibatkan satu orang atau lebih yang digunakan sebagai alasan pembandingan atau acuan dalam membentuk respon afektif dan respon kognitif serta melakukan perilaku. Kelompok acuan bisa berukuran berapa saja dari satu orang sampai ratusan orang) dan dapat diraba atau tidak diraba dan simbolis (Peter dan Olson, 2014).

Kelompok acuan/kelompok referensi juga secara tidak langsung terlibat dalam promosi produk, karena kelompok acuan berpengaruh cukup kuat terhadap pembelian oleh konsumen, meskipun pengaruhnya tidak semua sama. Konsep kelompok acuan digunakan pengiklan dalam upaya membujuk konsumen agar membeli produk dan merek, menggambarkan produk yang dikonsumsi di situasi yang menyenangkan secara sosial, penggunaan orang-orang terkenal/menarik, dan penggunaan anggota kelompok nyata sebagai duta iklan. Secara tidak langsung pemasar merujuk kepada kelompokkelompok acuan melalui upaya persuasif pemasaran produk dan merek mennjukkan kepercayaan bahwa kelompok acuan memaparkan kepada orang dengan perilaku dan gaya hidup, mempengaruhi tekanan untuk menyesuaikan diri dengan norma-norma kelompok (Peter dan Olson, 2014).

Berdasarkan pendapat dari para ahli diatas. Kelompok acuan adalah pembanding dalam membentuk respon kognitif, afektif dan perilaku seorang konsumen. Maka kelompok acuan dapat dikatakan sebagai acuan/kelompok referensi juga secara tidak langsung terlibat dalam promosi produk, karena kelompok acuan berpengaruh cukup kuat terhadap pembelian oleh konsumen, meskipun pengaruhnya tidak semua sama.

Petter dan Olson (2014) menyatakan bahwa pada dasarnya, orang mengidentifikasi dan mengafiliasi kelompok acuan karena tiga alasan, yaitu: (1) untuk memperoleh pengetahuan yang bermanfaat; (2) mendapatkan balasan (reward) dan menghindari hukuman; dan (3) mempelajari makna dari membentuk, memodifikasi, atau mempertahankan konsep diri.

Kelompok acuan memiliki faktor yang menentukan dimensinya melalui kekuatan pengaruhnya, yaitu informasional, utilitarian, dan ekspresif nilai: (1) Pengaruh Kelompok Acuan/Kelompok Referensi Informasional. Menyampaikan atau meneruskan informasi yang bermanfaat kepada konsumen mengenai diri mereka sendiri, orang lain, atau aspek lingkungan fisik, seperti produk, jasa, dan toko. Informasi ini dapat disampaikan secara langsung atau dengan demonstrasi langsung. Konsumen dipengaruhi kelompok acuan 
jika informasi dirasa dapat dipercaya dan relevan dengan masalah yang dihadapi dan sumber informasinya dapat dipercaya. Terdapat tiga cara dalam menyalurkan informasi dari kelompok acuan kepada konsumen, yait konsumen dengan sengaja mencari informasi untuk mengurangi risiko saat membuat keputusan atau untuk membantu mempelajari cara menunjukkan perilaku tertentu; (2) Pengaruh Kelompok Acuan/Kelompok Referensi Utilitarian. Pengaruh ini terjadi jika kelompok acuan mengontrol imbalan dan hukuman. Biasanya konsumen akan menuruti keinginan kelompok acuan bila mereka yakin kelompok acuan tersebut mau mengontrol imbalan dan hukuman, perilaku tersebut bisa terlihat atau dikenal oleh kelompok tersebut, dan konsumen termotivasi untuk memperoleh imbalan atau menghindari hukuman; (3) Pengaruh Kelompok Acuan/Kelompok Referensi Ekspresif Nilai. Hal ini mempengaruhi konsep diri orang lain, sebagai subbudaya, kelompok acuan memuat dan membentuk makna budaya (kepercayaan, nilai, norma perilaku, gaya hidup). Supranto dan Limakrisna (2011: 60) menambahkan bahwa orang selalu mencari makna budaya yang diinginkan untuk dipergunakan dalam membentuk, meningkatkan atau mempertahankan konsep diri mereka, dengan jalan mengenali dan mengafiliasi kelompok tertentu yang mengekspresikan makna ini dan menggunakannya dalam proyek 'self contruction' mereka sendiri.

$$
\begin{aligned}
& \text { 1. Informasional } \\
& \text { 2. Utilitarian } \\
& \text { 3. Ekspresif Nilai } \\
& \text { Peter dan Olson } \\
& \text { (2014) }
\end{aligned}
$$

1. Ketertarikan Mencari
Informasi Lebih Produk.
2. Mempertimbangkan
Membeli
3. Keinginan Mengetahui
Produk
4. Ketertarikan Mencoba
Produk
Schiffman dan Kanuk (2012)

\section{Gambar 3. Kerangka Penelitian}

Minat beli merupakan salah satu aspek psikologis yang memiliki pengaruh cukup besar terhadap sikap perilaku, sedangkan kelompok acuan dapat memberi dampak pada seseorang dengan tiga cara. Pertama orang tersebut akan menunjukkan perilaku dan gaya hidup yang baru. Kedua, ide ide dan imajinasi yang mempengaruhi minat individu akan disesuaikan dengan kelompok referensi. Ketiga, kondisi kompulsif yang diciptakan mungkin memiliki pengaruh pada pilihan merek. Artinya terdapat hubungan antara kelompok acuan terhadap minat beli melalui dampak yang diberikan. Hal tersebut dibuktikan dengan penelitian Nadiastika. et al (2016) yang menyebutkan bahwa terdapat pengaruh langsung dan signifikan antara kelompok acuan terhadap niat pembelian. Namun hal ini tidak sejalan dengan penelitian yang dilakukan oleh David, B Martin, et al (2017), yang menyatakan bahwa tidak ada pengaruh kelompok acuan terhadap minat beli.

$\mathrm{H}_{1}$ : Kelompok Acuan berpengaruh kuat dan positif terhadap Minat Beli. 


\section{Metode Penelitian}

Metode penelitian adalah cara ilmiah untuk mendapatkan data dengan tujuan dan kegunaan tertentu (Sugiyono, 2017). Penelitian ini menggunakan metode deskriptif dan metode verifikatif dengan pendekatan kuantitatif. Maka, dalam melakukan penelitian ini, akan digunakan pendekatan kuantitatif dengan metode survey.

Dalam sebuah penelitian terdapat variabel yang harus ditetapkan dengan jelas sebelum mulai pengumpulan data. Penelitian ini mencakup dua variable, yaitu minat beli (Y) sebagai variabel terikat (dependen variabel), dan kelompok acuan (X) sebagai variabel bebas (independen variabel) pada pengguna motor Yamaha NMAX. Untuk melakukan pengolahan data, diperlukan unsur lain yang berhubungan dengan variabel seperti konsep variabel, dimensi, indikator, ukuran, dan skala di mana variabel penelitian akan diukur dengan skala ordinal.

Teknik sampling adalah teknik menentukan sampel yang akan digunakan dalam penelitian (Sugiyono, 2017). Penelitian ini akan menggunakan teknik non-probability sampling dengan kriteria paling utama yaitu pengguna produk sepeda motor Yamaha NMAX 150CC yang berdomisili di Bandung dan merupakan pengikut akun instagram bandungnmaxofficial.

SEM dengan PLS merupakan suatu teknik alternatif pada analisis SEM dimana data yang dipergunakan tidak harus berdistribusi normal multivariat. Pada SEM dengan PLS nilai variabel laten dapat diestimasi sesuai dengan kombinasi linear dari variabelvariabel manifest yang terkait dengan suatu variabel laten serta diperlakukan untuk menggantikan variabel manifest. Menurut Monecke \& Leisch (2012) dalam Sarwono dan Narimawati (2015), SEM dengan PLS terdiri tiga komponen, yaitu:

\subsection{Model Struktural (Inner Model)}

Model struktural atau inner model menggambarkan model hubungan antar variabel laten yang dibentuk berdasarkan substansi teori. Model struktural dievaluasi dengan menggunakan $R$-square untuk konstruk.

Dependen, Stone-geisserq-square test untuk predictive relevance dan uji $\mathrm{t}$ serta signifikansi dari koefisien parameter jalur struktural.

Persamaan untuk model struktural untuk SEM PLS:

$$
\eta_{j}=\sum \beta_{j} \eta_{i}+\sum \gamma_{j} \xi_{b}+\zeta_{j}
$$

dimana:

i. b menyatakan indeks range sepanjang $i$ dan $b$

j menyatakan jumlah variabel laten endogen

$\beta_{\mathrm{ji}} \quad$ menyatakan koefisien jalur yang menghubungkan variabel laten endogen

( $\eta$ dengan endogen $(\eta)$

$\gamma_{\mathrm{jb}}$ menyatakan koefisien jalur yang menghubungkan variable laten endogen

( $)$ dengan eksogen $(\xi)$

$\zeta \quad$ menyatakan tingkat kesalahan pengukuran (inner residual variable) 


\subsection{Model pengukuran (outer model)}

Model pengukuran atau outer model menggambarkan hubungan antara variabel laten dengan variable manifestnya (indicator). Pada outer model terdapat dua jenis model yaitu model indikator formatif dan model indikator refleksif. Model refleksif terjadi apabila variabel manifest dipengaruhi oleh variabel laten, sedangkan model formatif mengasumsikan bahwa variabel manifest mempengaruhi variabel laten dengan arah kausalitas mengalir dari variabel manifest menuju variabel laten. Convergent validity dari model pengukuran dengan model reflektif indikator dinilai berdasarkan korelasi antara item score/component score dengan construct score yang dihitung dengan PLS. Ukuran reflektif dikatakan tinggi jika berkorelasi lebih dari 0,70 dengan konstruk yang ingin diukur. Namun demikian untuk penelitian tahap awal dari pengembangan skala pengukuran nilai loading 0,5 sampai 0,60 dianggap cukup (Chin, 1998 dalam Ghozali, 2006).

Persamaan untuk model indicator refleksif SEM PLS:

$$
\begin{aligned}
& x=\lambda_{x} \xi+\varepsilon_{x} \\
& y=\lambda_{y} \eta+\varepsilon_{y}
\end{aligned}
$$

dimana:

$\mathrm{x}$ menyatakan indikator untuk variabel laten eksogen $(\xi)$

y menyatakan indikator untuk variabel laten endogen $(\eta)$

$\lambda_{\mathrm{x}}, \lambda_{\mathrm{y}}$ menyatakan loading matrix yang menggambarkan seperti koefisien regresi sederhana yang menghubungkan variabel laten dengan indikatornya sedangkan persamaan untuk model indicator formatif:

$$
\begin{gathered}
\xi=\Pi_{x} \xi X_{i}+\delta \xi \\
\eta=\Pi_{y} \eta Y_{i}+\varepsilon \eta
\end{gathered}
$$

Dimana:

Пх , Пу menyatakan seperti koefisien regresi berganda dari variabel laten terhadap indikator

$\delta \xi, \varepsilon \eta$ menyatakan tingkat kesalahan pengukuran (residual error)

Metode lain untuk menilai discriminant validity adalah membandingkan nilai square root of Average Variance Extracted (AVE) setiap konstruk dengan korelasi antara konstruk lainnya dalam model. Jika nilai akar AVE setiap konstruk lebih besar daripada nilai korelasi antar konstruk dengan konstruk lainnya dalam model, maka dikatakan memiliki nilai discriminant validity yang baik. Pengukuran ini dapat digunakan untuk mengukur reabilitas component score variabel laten dan hasilnya lebih konservatif dibandingkan dengan composite reability. Direkomendasikan nilai AVE harus lebih besar 0,50 (Fornnel dan Larcker, 1981 dalam Ghozali, 2006). Composite reability yang mengukur suatu konstruk dapat dievaluasi dengan dua macam ukuran yaitu internal consistency dan Cronbach's Alpha (Ghozali, 2006). 


\subsection{Skema pembobotan. (weight relation)}

Bagian ketiga ini merupakan ciri khusus SEM dengan PLS dan tidak ada pada SEM berbasis kovarian. Menurut Abdillah dan Jogiyanto (2015), skor weight relation menunjukan hubungan nilai varian antara indikator dengan variabel latennya. Persamaaan untuk weight relation adalah:

$\xi_{b}=\Sigma_{k} W_{k} X k$

$\eta_{i}=\Sigma_{k} W_{k} y_{k}$

\section{Dimana:}

$\mathrm{W}_{\mathrm{kb}}$, Wki menyatakan bobot $\mathrm{k}$ yang digunakan untuk mengestimasi variabel laten $\xi_{\mathrm{b}}$ dan $\eta_{\mathrm{i}}$

\section{Pengujian Hipotesis}

PLS tidak mengasumsikan data berdistribusi normal, sebagai gantinya PLS bergantung pada prosedur bootstrap non-parametrik untuk menguji signifikansi koefisiennya (Hair, et al., 2014).

Hipotesis statistik untuk outer model :

$\mathrm{HO}: \lambda_{\mathrm{jk}}=0$

$\mathrm{H} 1: \lambda_{\mathrm{jk}} \neq 0$

Hipotesis statistik untuk inner model :

$\mathrm{HO}:$ dugaan parameter $=0$

$\mathrm{H} 1$ : dugaan parameter $\neq 0$

Statistik uji yang dgunakan adalah uji t, dengan rumus sebagai berikut:

$t=\frac{\lambda_{j k}}{S E^{*}\left(\lambda_{j k}\right)}$, untuk uji terhadap outer model

$t=\frac{\text { dugaan parameter }}{S E^{*}(\text { dugaan parameter })}$, untuk uji terhadap inner model

$\mathrm{SE}^{*}$ (dugaan parameter) adalah standar error yang diperoleh dari bootstrapping. Uji statistik mengikuti distribusi $t$ dengan derajat bebas $(d b)=n-1$.

\section{Hasil dan Pembahasan}

Deskripsi data yang disajikan dalam bagian ini meliputi data variabel: kelompok acuan (X) dan minat beli (Y). Seperti telah diuraikan dalam bab sebelumnya, penelitian ini bersifat kausal yang mengkaji kompleksitas hubungan antara variabel-variabel yang diteliti, dimana jenis variabel yang digunakan adalah variabel dependent (variabel terikat) dan variabel independent (variabel bebas). Dalam penelitian ini, variabel dependent adalah minat beli (Y), sedangkan variabel independent-nya adalah kelompok acuan (X). Pada penelitian ini dapat dikontraksi diagram jalur dengan menggunakan batuan software Smart PLS versi 3.3.2 yang memiliki tampilan output dan diagram jalur yang baik, seperti hasil gambar variabel laten dan indikator pada Gambar 1 dibawah: 


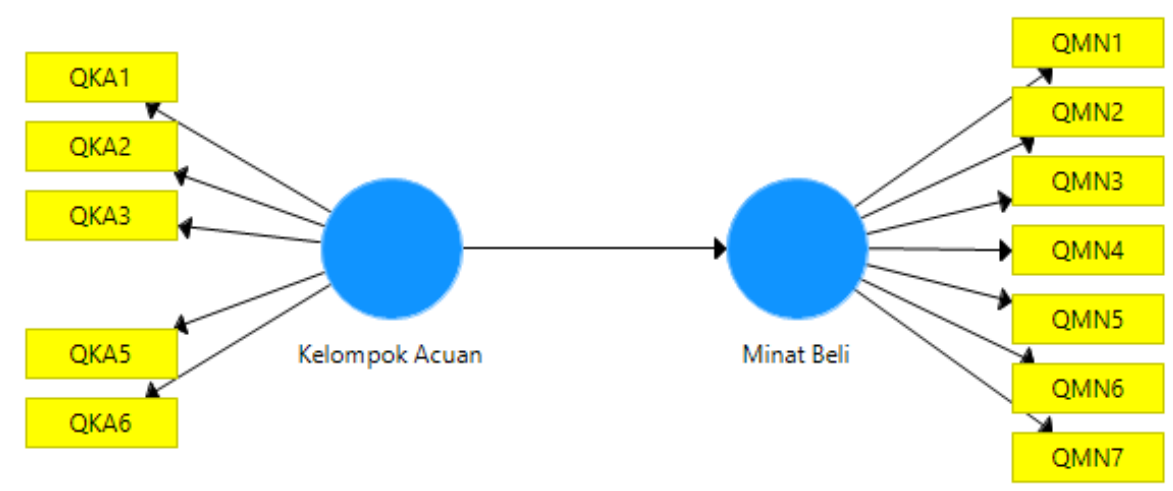

Gambar 4. Perubahan Hasil Smart PLS

Berdasarkan Gambar 4 diatas, maka nanti akan mendapat hasil ukuran individual dikatakan valid jika memiliki korelasi (loading) dengan konstruk (variabel laten) yang ingin diukur $\geq 0,5$ atau nilai T-statistiknya harus $\geq 1,96$ (uji dua pihak) pada level signifikansi 0,05. Jika salah satu indikator memiliki nilai loading $<0,5$ atau T-statistik $<$ 1,96, maka indikator tersebut harus dibuang (didrop) karena mengindikasikan bahwa indikator tidak cukup baik untuk mengukur konstruk secara tepat.

Tabel 3. Hasil Outer Loading Validitas

\begin{tabular}{|c|c|c|c|c|c|c|}
\hline \multirow{3}{*}{ Konstruk } & Indikator & $\begin{array}{c}\text { Original } \\
\text { Sample } \\
(\mathbf{O})\end{array}$ & $\begin{array}{c}\text { Sample } \\
\text { Mean } \\
(\mathbf{M})\end{array}$ & $\begin{array}{c}\text { Standard } \\
\text { Deviation } \\
\text { (STDEV) }\end{array}$ & $\begin{array}{c}\text { T Statistics } \\
(\mid \mathbf{O} / \text { STDEV } \mid \text { ) }\end{array}$ & Keterangan \\
\hline \multirow{4}{*}{$\begin{array}{c}\text { Kelompok } \\
\text { Acuan }\end{array}$} & Infomasional 1 & 0.866 & 0.869 & 0.028 & 30.897 & Valid \\
\cline { 2 - 7 } & Infomasional 2 & 0.911 & 0.909 & 0.020 & 46.093 & Valid \\
\cline { 2 - 7 } & Infomasional 3 & 0.676 & 0.660 & 0.089 & 7.598 & Valid \\
\cline { 2 - 7 } & Utilitarian & 0.648 & 0.623 & 0.100 & 6.507 & Valid \\
\cline { 2 - 7 } & Ekspresif Nilai & 0.603 & 0.589 & 0.104 & 5.806 & Valid \\
\cline { 2 - 7 } & MN 1 & 0.735 & 0.722 & 0.075 & 9.825 & Valid \\
\cline { 2 - 7 } Beli & MN 2 & 0.594 & 0.557 & 0.143 & 4.142 & Valid \\
\cline { 2 - 7 } & MN 3 & 0.668 & 0.629 & 0.137 & 4.872 & Valid \\
\cline { 2 - 7 } & MN 4 & 0.804 & 0.806 & 0.035 & 22.702 & Valid \\
\cline { 2 - 7 } & MN 5 & 0.578 & 0.551 & 0.117 & 4.940 & Valid \\
\cline { 2 - 7 } & MN 6 & 0.772 & 0.777 & 0.062 & 12.504 & Valid \\
\hline
\end{tabular}

Sumber : Hasil Uji Smart PLS, 2020

Berdasarkan seluruh hasil pengujian validitas pada Tabel 1 diketahui bahwa semua indikator telah signifikan secara statistik dan valid dalam mengukur indikatornya masingmasing. Namun, ada satu indikator "penggunaa produk yang dianjurkan" $(X)$ ke empat pada dimensi utilitarian yang harus dieliminasi seperti yang ada di Gambar 1 sehingga menghasilkan pengujian diatas dan dapat dilakukan analisis lebih lanjut. Indikator yang memiliki sumbangan efektif terbesar pada setiap indikator dapat diketahui dengan melihat sampel mean yang diperoleh dari hasil bootstrapping pada SmartPLS. Indikator yang memiliki sumbangan efektif terbesar terhadap variabel minat beli adalah indikator kedua (Y) dengan sebesar 0,911. Sedangkan pada variabel kelompok acuan memiliki sumbangan efektif terbesar pada indikator ketujuh (X) sebesar 0,840 .

Pada penelitian ini, uji reliabilitas menggunakan composite reliability, yang disajikan pada Tabel 4: 
Tabel 4. Hasil Uji Reliabilitas Model

\begin{tabular}{|l|c|c|c|c|}
\hline & $\begin{array}{c}\text { Cronbach's } \\
\text { Alpha }\end{array}$ & rho_A & $\begin{array}{c}\text { Composite } \\
\text { Reliability }\end{array}$ & $\begin{array}{c}\text { Average Variance } \\
\text { Extracted (AVE) }\end{array}$ \\
\hline Kelompok Acuan & 0.814 & 0.891 & 0.863 & 0,564 \\
\hline Minat Beli & 0.851 & 0.888 & 0.881 & 0,517 \\
\hline
\end{tabular}

Sumber : Hasil Uji Smart PLS, 2020

Berdasarkan Tabel 4, hasil uji reliabilitas komposit untuk variabel minat beli dan variabel kelompok acuan yang dijelaskan oleh melalui tiga dimensi memiliki $\rho c>0,7$ dan nilai AVE yang lebih besar dari 0,50 . Dimana terdapat variabel minat beli yaitu dengan hasil dari indikator dimensi ketertarikan mencari informasi lebih produk, mempertimbangkan membeli, keinginan mengetahui produk, dan ketertarikan mencoba produk. Lalu, variabel kelompok acuan yang dihasilkan dari indikator dimensi informasional, utilitarian, dan ekspresif nilai. Berarti indikator-indikator yang digunakan benar-benar dapat dipercaya untuk diukur dalam konstruknya.

Dari inner model diketahui terdapat satu variabel terikat yaitu minat beli. Dari output PLS diperoleh harga koefisien determinasi untuk variabel terikat seperti disajikan pada tabel 5:

Tabel 5. Hasil Uji Inner Model

\begin{tabular}{|l|c|c|}
\hline & R Square & R Square Adjusted \\
\hline Minat Beli & 0.321 & 0.314 \\
\hline
\end{tabular}

Sumber : Hasil Uji Smart PLS, 2020

Analisis korelasi digunakan untuk mencari besarnya korelasi antara kelompok acuan (X) terhadap minat beli (Y). Berdasarkan Tabel 3 di atas, diperoleh nilai koefisien (R square) sebesar 0,321 artinya hubungan diantara dua variabel kuat dan hubungan searah artinya apabila Variabel kelompok acuan semakin meningkat maka minat beli akan semakin baik/meningkat juga. Artinya, indikator pada setiap dimensi variabel kelompok acuan memiliki pengaruh terhadap minat beli konsumen sebesar $32,1 \%$ dan sisanya $67,9 \%$ pengaruh diluar penelitian. Maka dapat dikatakan pemodelan yang dibentuk dikategorikan sebagai model yang baik.

Tabel 6. Hasil Uji T (Parsial)

\begin{tabular}{|l|c|c|c|c|c|c|}
\hline & $\begin{array}{c}\text { Original } \\
\text { Sample (O) }\end{array}$ & $\begin{array}{c}\text { Sample } \\
\text { Mean (M) }\end{array}$ & $\begin{array}{c}\text { Standard Deviation } \\
\text { (STDEV) }\end{array}$ & $\begin{array}{c}\text { T Statistics } \\
(\text { OS/STDEV) }\end{array}$ & P Values & Keterangan \\
\hline$X \rightarrow Y$ & 0.566 & 0.590 & 0.051 & 11.191 & 0.000 & $\mathrm{H}_{0}$ ditolak \\
\hline
\end{tabular}

Sumber : Hasil Uji Smart PLS, 2020

Lalu, berdasarkan data Tabel 4 dapat diketahui bahwa nilai t-statistics kelompok acuan (x) $>$ dari t-tabel sebesar 1,985 dan nilai $\mathrm{P}$ Value $\mathrm{X}<0,05$ maka $\mathrm{H}_{0}$ ditolak dan $\mathrm{H}_{1}$ diterima yang artinya kelompok acuan memiliki pengaruh terhadap minat beli.

Berdasarkan keseluruhan hasil data yang telah diperoleh dan diolah, peneliti menemukan hasil bahwa kelompok acuan memiliki pengaruh yang baik dan positif pada minat beli pada setiap pengguna sepeda motor Yamaha NMAX di kota Bandung dan Instagram bandungnmaxofficial dengan total $32,1 \%$ pengaruh yang mampu diberikan akan sebuah minat beli pada sepeda motor Yamaha NMAX terutama Yamaha NMAX 150CC di kota Bandung. 


\section{Kesimpulan}

Dengan hasil analisis mengenai subjek dan objek penelitian yang telah dilakukan dengan memperhatikan aspek teoritis maupun aspek praktisnya yang kemudian terolah dan terkumpul pada analisis mengenai pengaruh kelompok acuan terhadap minat beli pada konsumen yamaha nmax di kota Bandung. Maka, dapat disimpulkan bahwa hasil dari penelitian ini adalah cukup kuat, positif dan signifikan pada setiap variabel dimensi total langsung kelompok acuan berupa informasional, utilitarian, dan ekspresif nilai.

Implikasi studi ditujukan untuk industri otomotif terutama sepeda motor terutama Yamaha, yang dimana diharapkan dapat menjadi salah satu acuan dan pengoptimalan dalam bisnis untuk dapat meningkatkan strategi marketing and promotion pada sepeda motor atau melalui sosial media yang semakin berkembang ke dalam peluang dan proses suatu bisnis. Pada indikator kelompok acuan informasional "pembagian pengalaman penggunaan produk" memiliki nilai yang cukup besar dan ekspresif nilai "tertarik menggunakan produk bersama teman" menjadi nilai yang cukup rendah dibandingkan yang lainnya. Artinya komentar atau WOM yang dilakukan masih menjadi cara yang sangat efektif dan mampu memberikan dampak para konsumen yang ingin memilih motor atau mencari referensi sepeda motor, sedangkan penggunaan dalam jumlah yang dilakukan untuk bersama teman/saudara tidak bisa dijadikan tolak ukur dalam para konsumen ingin memilih dan menentukan pembelian/pemakaian sepeda motor Yamah NMAX. Lalu, pada indikator minat beli "keinginan untuk mencoba produk" memiliki nilai yang cukup besar dan ekspresif nilai "mengetahui lebih mengenai produk" menjadi nilai yang cukup rendah dibandingkan yang lainnya. Artinya, konsumen memiliki ketertarikan yang cukup tinggi akan pembelian atau kepuasan pemakain sepeda motor Yamah NMAX, namun beberapa konsumen yang sudah diberikan informasi tidak terlalu menanggapi dan ingin mengetahui lebih tentang sepeda motor Yamaha NMAX.

Keterbatasan research ini adalah kurang indikator dari variabel kelompok acuan dimensi kelompok acuan yaitu, ekpresif nilai yang seharusnya memiliki indikator pembanding lebih untuk dapat melihat nilai-nilai dan keunggulan yang diberikan sebuah konsume kepada perusahaan sepeda motor dalam tingkat market place. Perusahaan juga dapat meningkatkan minat beli dengan cara mengadakan potongan harga/cashback, event kerjasama komunitas motor, atau lebih memperhatikan harga/kualitas biaya pelayanan produk dan jasa pasar saat ini. Sehingga dengan begitu produk dan jasa yang ditawarkan mampu menarik minat transaksional dan kepuasan konsumen terhadap produk Yamaha Nmax. Selain hal tersebut, masih banyak variable minat beli/kelompok acuan dengan dimensi lain dari sumber dan peneliti lain yang dapat dijadikan bahan untuk riset pemahaman konsumen lebih baik dalam suatu bisnis. Dapat juga mencari dan mengganti variable untuk mendapatkan hasil riset yang lebih mendalam dan baik melalui berbagai sumber jurnal yang lebih menarik pada bidang otomotif. Saran untuk penelitian selanjutnya yakni dapat menggunakan variabel lain seperti kualitas produk, Brand Switching atau harga yang dapat dijadikan sebagai variabel untuk mempengaruhi Minat Beli hal ini dilakukan agar hasil yang ditemukan lebih maksimal.

\section{Referensi}

David Billy Martin Salangka, et al. (2017). The Influence Of Reference Group And Brand Image On Buying Interest Of Smartphone. Jurnal EMBA Vol.5 No.3 September 2017. 
E. DESI ARISTA \& SRI RAHAYU TRI ASTUTI. (2011). Analisis Pengaruh Iklan, Kepercayaan Merek, dan Citra Merek terhadap Minat Beli Konsumen. Aset, Maret 2011, hal. 37-45 ISSN 1693-928X.

Hatane Semuel, et al. (2014). Analisis Ewom, Brand Image, Brand Trust Dan Minat Beli Produk Smartphone Di Surabaya. Jurnal Manajemen Pemasaran, Vol. 8, No. 2, Oktober 2014 ISSN 1907-235X.

Jennifer Adji,et al. (2014). Pengaruh Satisfaction Dan Trust Terhadap Minat Beli Konsumen (Purchase Intention) Di Starbucks The Square Surabaya. Jurnal Manajemen Pemasaran Petra Vol. 2, No. 1, (2014) 1-10 PENGARUH.

Nadiastika Hayyuna Zahra, et al. (2016). Pengaruh Kelompok Acuan Terhadap Sikap Dan Niat Pembelian Serta Dampaknya Pada Keputusan Pembelian (Survei pada Konsumen di Rumah Makan Kimbap Rina, Malang. Jurnal Administrasi Bisnis (JAB)|Vol. 37 No. 2 Agustus 2016.

Petter, J. \& Olson, J. (2014). Consumen Behavior \& Marketing Strategy (Perilaku Konsumen \& Strategi Pemasaran) Edisi 9 buku 2. Jakarta: Salemba Empat.

Purwati, et al. 2012. Pengaruh Harga dan Kualitas Produk Terhadap Keputusan Pembelian Motor Honda Matic Beat (Studi Kasus pada PT. Nusantara Solar Sakti). Jurnal Ekonomi dan Informasi Akuntansi (Jenius)Vol. 2 No. 3 Sept 2012.

Rosiana, Tri Handayani. (2012). Bauran Pemasaran. Edisi 12 jilid 2. Jakarta: Erlangga.

S, Emyria Natalia br, dkk. (2017). Analisis Kepuasan Masyarakat Terhadappelayanan Publik Menggunakan Pendekatanpartial Least Square (PLS). Jurnal Gaussian, Volume 6, Nomor 3, Tahun 2017, Halaman 313-323.

Sarwono, J., dan Narimawati, U. (2015). Membuat Skripsi, Tesis dan Disertasi dengan Partial Least Square SEM (PLS-SEM). Yogyakarta: Penerbit ANDI.

Schiffman, L., dan Kanuk, L. (2012). Consumer Behavior. 10th Edition. New Jersey: Pearson Prentice Hall.

Sedarmayanti dan Hidayat, Syarifudin. (2011). Meteodologi penelitian. Bandung: Mandar Maju.

Setiadi, J Nugroho. (2013). Perilaku Konsumen. Jakarta : Kencana Prenada Media Group. Sugiyono. (2017). Metode Penelitian Bisnis. Bandung:Alfabeta.

Sugiyono. (2017). Metode Penelitian Kuantitatif, Kualitatif, dan R\&D. Bandung: Alfabeta.

Sugiyono. (2017). Statistik Untuk Penelitian. Bandung: Alfabeta.

Supranto, J., \& Limakrisna, N. (2011). Perilaku Konsumen \& Strategi Pemasaran (Untuk Memenangkan Persaingan BIsnis) edisi kedua. Jakarta: Mitra Wacana Media.

Suryani, Tatik. (2013). Perilaku Konsumen di Era Internet. Yogyakarta: Graha Ilmu.

Syofian, Siregar. (2013). Metode Penelitian Kuantitatif. Jakarta: Kencana Prenada Media Group. 


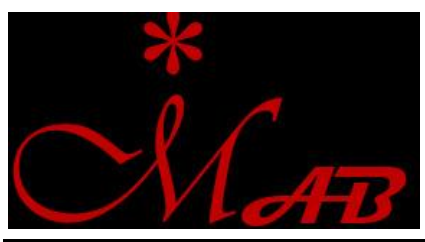

Jurnal Ilmu Sosial, Manajemen, Akuntansi, \& Bisnis p-ISSN $x x x x x-x x x x$, e-ISSN: $x x x x-x x x x x$ Vol. 1, No. 1, Agustus 2020

\section{Copyrights}

Copyright for this article is retained by the author(s), with first publication rights granted to the journal.

This is an open-access article distributed under the terms and conditions of the Creative Commons Attribution license (http://creativecommons.org/licenses/by/4.0/) 